Louisiana State University

LSU Digital Commons

Faculty Publications

Department of Biological Sciences

3-1-2009

\title{
Supplemental irrigation increases seedling performance and diversity in a tropical forest
}

\author{
C. E.Timothy Paine \\ Louisiana State University \\ Kyle E. Harms \\ Louisiana State University \\ Jess Ramos \\ Asociación para la Conservación de la Cuenca Amazónica
}

Follow this and additional works at: https://digitalcommons.Isu.edu/biosci_pubs

\section{Recommended Citation}

Paine, C., Harms, K., \& Ramos, J. (2009). Supplemental irrigation increases seedling performance and diversity in a tropical forest. Journal of Tropical Ecology, 25 (2), 171-180. https://doi.org/10.1017/ S0266467408005798

This Article is brought to you for free and open access by the Department of Biological Sciences at LSU Digital Commons. It has been accepted for inclusion in Faculty Publications by an authorized administrator of LSU Digital Commons. For more information, please contact ir@lsu.edu. 


\title{
Supplemental irrigation increases seedling performance and diversity in a tropical forest
}

\section{E. Timothy Paine ${ }^{*, 1}$, Kyle E. Harms ${ }^{*} \dagger$ and Jesús Ramos $\ddagger$}

\author{
* Department of Biological Sciences, Louisiana State University, Baton Rouge, LA, USA \\ $\dagger$ Smithsonian Tropical Research Institute, Apartado 2072, Balboa, Panama \\ $\ddagger$ Asociación para la Conservación de la Cuenca Amazónica, Puerto Maldonado, Jiron Cusco 499, Puerto Maldonado, Peru \\ (Accepted 6 December 2008)
}

\begin{abstract}
Diversity is positively correlated with water availability at global, continental and regional scales. With the objective of better understanding the mechanisms that drive these relationships, we investigated the degree to which variation in water availability affects the performance (recruitment, growth and survival) of juvenile trees. Precipitation was supplemented throughout two dry seasons in a seasonal moist forest in south-eastern Peru. Supplementing precipitation by $160 \mathrm{~mm} \mathrm{mo}^{-1}$, we increased soil moisture by $17 \%$. To generate seedling communities of known species composition, we sowed 3840 seeds of 12 species. We monitored the fates of the 554 seedlings recruited from the sown seeds, as well as 1856 older non-sown seedlings $(10 \mathrm{~cm} \leq$ height $<50 \mathrm{~cm})$, and 2353 saplings $(>1 \mathrm{~m}$ tall). Watering significantly enhanced young seedling growth and survival, increasing stem density and diversity. Watering diminished the recruitment of species associated with upland forests, but increased the survival of both upland- and lowland-associated species. Though supplemental watering increased the growth of older seedlings, their density and diversity were unaffected. Sapling performance was insensitive to watering. We infer that variation in dry-season water availability may affect seedling community structure by differentially affecting recruitment and increasing overall survival. These results suggest that differential seedling recruitment and survival may contribute to the observed relationships between water availability, habitat associations and patterns of tree species richness.
\end{abstract}

Key Words: diversity, Estación Biológica Los Amigos, habitat filtering, palms, Peru, precipitation, seasonality, seedling recruitment

\section{INTRODUCTION}

Water availability strongly influences tree species diversity at continental and regional scales, and helps shape patterns of habitat association at local scales. At continental scales, water availability is strongly positively correlated with tree diversity (Allen et al. 2002, Kreft \& Jetz 2007). Within tropical regions, including the Amazon Basin, there is a significant positive correlation between precipitation and local tree diversity (Clinebell et al. 1995, Phillips et al. 1994). More locally, for example, along the foothills of Western Amazonia, tree diversity is greater in the aseasonal ever-wet forests of Ecuador than in the seasonal moist forests of south-east Peru (Pitman et al. 2002). Despite the ubiquity of the positive correlations

\footnotetext{
${ }^{1}$ Corresponding author. Current address: UMR EcoFoG-ENGREF, Campus agronomique, BP 709, 97379 Kourou cedex, French Guiana. Email: timothy.paine@ecofog.gf
}

between diversity and precipitation across scales, we lack a complete understanding of the mechanism(s) that give rise to these relationships.

The frequency and intensity of droughts may play an important role. In many tropical forests, seasonal droughts occur once or twice per year, depending primarily on latitude. Droughts related to El NiñoSouthern Oscillation cycling have been linked to increased seedling and adult tree mortality in Amazonia, Malaysia and Central America (Condit et al. 2004, Delissio \& Primack 2003, Williamson et al. 2000). The clearest evidence of the effects of sustained drought in a tropical forest comes from Brazil, where a 3-y experimental reduction in precipitation increased the mortality of stems $>2 \mathrm{~cm}$ dbh by $38 \%$ (Nepstad et al. 2007).

Drought, seasonal or otherwise, imposes an ecological filter (sensu Harper 1977) that removes droughtintolerant individuals from a community, and may reduce its diversity. One hypothesis for the lower diversity 
of seasonal moist tropical forests, as compared with aseasonal wet forests (Pitman et al. 2002) is that to persist in seasonal forest, individuals must be to some degree drought-tolerant. Should drought remove all individuals of a species from a community, its species richness would be reduced. In accordance with this hypothesis, drought tolerance varies widely among species, and the prevalence of drought tolerance declines across a gradient of increasing precipitation in Panama (Engelbrecht \& Kursar 2003, Engelbrecht et al. 2007). In French Guiana, habitat associations of species were concordant with tolerance of experimental drought (Baraloto et al. 2007). Together, these studies suggest that variation in drought tolerance may play a substantial role in generating habitat associations, and limiting local diversity (Engelbrecht \& Kursar 2003, Harms et al. 2001).

In this study, we experimentally supplemented precipitation throughout two consecutive dry seasons in a seasonal moist forest to better understand the mechanisms that underlie the relationships between precipitation and diversity. Wright (1992) hypothesized that increased water availability increases local diversity by ameliorating competition for soil moisture and by increasing year-round host-specific pathogen and herbivore pressure. This may occur via several pathways. Diversity may be affected through changes in survival: diversity could be enhanced by increased overall survival, or increased survival of drought-intolerant species (Tanner \& Barberis 2007). Increased water availability could also affect diversity by increasing growth rates, since rates of growth and survival for juvenile forest trees are positively correlated (Fisher et al. 1991, Yavitt \& Wright 2008). A third, and previously untested, pathway by which increased water availability may affect diversity is by enhancing recruitment of all species, or drought-intolerant species. To test the support for these mechanisms, we assessed individual performance, measured as recruitment, survival and growth, for three subsets of the juvenile tree community: seedlings recruited from sown seeds, non-sown older seedlings, and saplings. We focused on juvenile trees since they may be most susceptible to changes in water availability, due to their limited root systems and competition with adults for soil moisture (Lewis \& Tanner 2000). Working with synthetic communities derived from sown seeds further allowed us to test the hypothesis that species associated with lowland forests would respond more positively to increased water availability than would species associated with upland forests, which are presumably more drought-tolerant.

\section{STUDY SITE AND SPECIES}

This study was conducted at the Centro de Investigación y Capacitación Río Los Amigos (CICRA), in south-

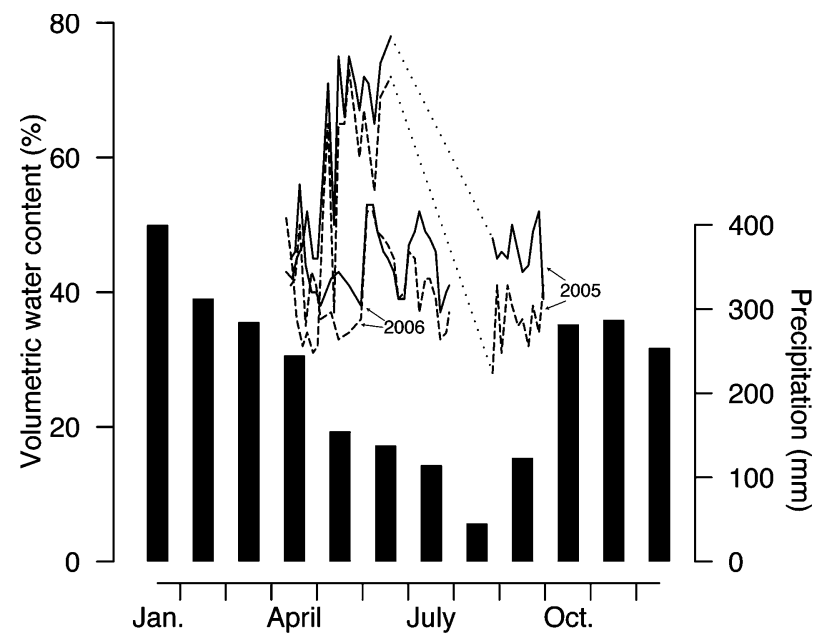

Figure 1. Mean monthly precipitation (bars) and fortnightly soil moisture in watered (solid lines) and unwatered (dashed lines) plots of seasonal Amazonian moist forest in 2005 and 2006. Precipitation was supplemented twice weekly in watered plots throughout the dry seasons (mid-April-mid-September) of 2005 and 2006, but soilmoisture measurements were not available from all periods. Watered plots were consistently wetter than unwatered plots, by an average of $17 \%$, and soil moisture in 2006 was substantially less than in 2005. Dotted lines indicate a period of missing data in 2005.

eastern Amazonian Peru $\left(12.57^{\circ} \mathrm{S} ; 70.10^{\circ} \mathrm{W} ; 280 \mathrm{~m}\right.$ asl). The site is characterized as tropical moist forest (Holdridge 1947). Annual precipitation between 2000 and 2007 was $2628 \pm 495 \mathrm{~mm}$ (mean \pm SD), with substantial seasonal variation in precipitation (http://atrium.andesamazon.org). A common definition of dry-season length is the number of months with less than $100 \mathrm{~mm}$ precipitation (Bunker \& Carson 2005). By that definition, the average dry season lasted only $4 \mathrm{wk}$ (occurring in August; Figure 1). Nevertheless, the dry season is generally considered to span May-September, during which period mean monthly precipitation in the 8 -y period was $114 \mathrm{~mm}$. The forests of the Río Los Amigos watershed are extremely diverse, containing at least 380 species of tree (http://atrium.andesamazon.org).

As in Paine \& Harms (in press), species were included in the seed-addition experiments of this study based upon three criteria. First, fruit needed to be available in March 2005, when seeds were added. Second, their seeds had to be sufficiently large to be easily cleaned and sown. Third, fruiting adults had to be sufficiently common and fecund to provide 400 seeds per species for sowing. These criteria yielded 12 species of canopy tree, representing nine families, all of which are primarily vertebrate-dispersed and shade-tolerant (Foster \& Janson 1985). Mean adult abundances and seed masses were determined from censuses of 20.5 ha in floodplain and terra firme forests of the Madre de Dios watershed (C. Vela, unpubl. data; J. Terborgh et al. unpubl. data). Adult abundances of the 12 species ranged from $<0.01-45$ 
Table 1. Species sown in the watering experiment, sorted by family. Preferred habitat information is based on plot censuses and personal observations. Seed masses are air-dry weights (mean $\pm \mathrm{SE}$ ), with sample size in parentheses, except for $B$. excelsa which is oven-dry weight (Peña-Claros \& de Boo 2002), and S. mombin, which is air-dry endocarp weight. Habitat association codes are as follows: FP - Floodplain forest, TF - Terra firme forest.

\begin{tabular}{llccc}
\hline Family & \multicolumn{1}{c}{ Species } & Seed mass (g) & Habitat association & Adult density $\left(\mathrm{ha}^{-1}\right)$ \\
\hline Anacardiaceae & Spondias mombin L. & $3.68 \pm 0.25(25)$ & $\mathrm{FP}$ & 2.60 \\
Arecaceae & Iriartea deltoidea Ruiz \& Pav. & $3.86 \pm 0.13(10)$ & $\mathrm{FP}$ & 39.5 \\
& Socratea exorrhiza (Mart.) H.Wendl. & $3.44 \pm 0.18(10)$ & $\mathrm{FP}$ & 1.32 \\
& Wettinia augusta Poepp. \& Endl. & $2.35 \pm 0.15(24)$ & $\mathrm{TF}$ & $<0.01$ \\
Caesalpiniaceae & Hymenaea oblongifolia Huber & $3.22 \pm 0.07(25)$ & $\mathrm{TF}$ & 0.05 \\
Clusiaceae & Calophyllum brasiliense Cambess. & $2.52 \pm 0.12(44)$ & $\mathrm{FP}$ & 0.23 \\
Flacourtiaceae & Carpotroche longifolia (Poepp.) Benth. & $0.14 \pm 0.0054(3)$ & $\mathrm{TF}$ & 0.05 \\
& Casearia sp. nov. & $0.61 \pm 0.014(25)$ & $\mathrm{FP}$ & 0.10 \\
Lecythidaceae & Bertholletia excelsa Bonpl. & $6.5 \pm 1.5$ & $\mathrm{TF}$ & $<0.01$ \\
Myristacaceae & Otoba parvifolia (Markgr.) A. H. Gentry & $1.80 \pm 0.043(14)$ & $\mathrm{FP}$ & 45.9 \\
Rubiaceae & Genipa americana L. & $0.051 \pm 0.001(25)$ & $\mathrm{FP}$ & 0.62 \\
Verbenaceae & Vitex cymosa Bertero ex Spreng. & $0.50 \pm 0.031(25)$ & $\mathrm{FP}$ & 0.24 \\
\hline
\end{tabular}

treesha $^{-1}\left(\right.$ median $=2.4$ trees ha $\left.^{-1}\right)$, and seed mass range was $0.05-6.5 \mathrm{~g}$ (median $=2.4 \mathrm{~g})$. We refer to upland, never-flooded forests as 'terra firme', and to lowland forests in the floodplains of the Río Madre de Dios and Río Los Amigos as 'floodplain' forests. Species associations with terra firme or floodplain forests were determined by inspection of the census data used to compile adult abundances. Four species are primarily found in terra firme forest, with the remaining eight species associated with floodplain forest. One terra firme-associated species (Bertholletia excelsa) failed to recruit any seedlings, and is not included in any analyses. Mean seed mass did not differ significantly between terra firme and floodplainassociated species $\left(\mathrm{F}_{1,9}=0.99, \mathrm{P}=0.34\right)$, as both smalland large-seeded species were associated with each forest type. Species names and distinguishing characteristics are presented in Table 1.

\section{METHODS}

We selected a relatively homogeneous 0.5 -ha site that was free of recent tree-fall gaps and inundated swales adjacent to Cocha Lobo, an oxbow lake formed by lateral migration of the Río Los Amigos. In March 2005, at the end of the rainy season, we laid out a grid of eight $20 \times 20$-m plots, separated from each other by at least $10 \mathrm{~m}$ (Figure 2). In watered plots, nine sprinkler heads arranged in a square grid evenly supplied supplemental precipitation. Sprinkler heads sprayed water $10 \mathrm{~m}$, so that every point (except for along plot borders) would receive water from four sprinklers, if not for interception by vegetation (as in Wright \& Cornejo 1990). These were supplied via PVC pipes by a $3.7 \mathrm{~kW}$ gasoline-powered selfpriming pump, which delivered water from Cocha Lobo at an approximate rate of $15 \mathrm{~m}^{3} \mathrm{~h}^{-1}$.

We supplied supplemental precipitation throughout the dry seasons (mid-April-mid-September) of 2005 and
2006. The sprinkler system was operated twice weekly for approximately $2 \mathrm{~h}$ each time, without regard to the quantity of natural precipitation. The rate of water application was sufficiently slow to avoid substantial above-ground surface flow. To assess the efficacy of our watering treatment, we measured soil moisture to a depth of $15 \mathrm{~cm}$ in watered and unwatered plots with time domain reflectometry (TDR 200, Spectrum Technologies, Inc.). Precipitation, natural and supplementary, was measured with simple rain gauges placed in watered and unwatered plots at a height of $1.5 \mathrm{~m}$. These measurements were made immediately before each watering event (i.e. 3 or $4 \mathrm{~d}$ following the previous watering event). They provide therefore a conservative estimate of the effectiveness of our watering treatment.

In each of the eight $20 \times 20-\mathrm{m}$ plots, we tagged, identified and measured every sapling $>1 \mathrm{~m}$ in height and $\leq 10 \mathrm{~cm} \mathrm{dbh}$ (diameter at breast height; $140 \mathrm{~cm}$ ). For small saplings, defined as $\leq 1 \mathrm{~cm}$ dbh, we measured height to the nearest $5 \mathrm{~cm}$. For large saplings, defined as $\mathrm{dbh}>1 \mathrm{~cm}$, we measured dbh to the nearest $\mathrm{mm}$. Within each $20 \times 20-m$ plot, we randomly located 24 pairs of $1-\mathrm{m}^{2}$ circular subplots to assess the seedling layer. In one of each pair of subplots, we monitored the growth and survival of all woody seedlings between 10 and $50 \mathrm{~cm}$ in height. Species from primarily scandent taxa (e.g. Byttneria (Sterculiaceae), Menispermaceae, most Sapindaceae and most Malpighiaceae) were excluded. The other subplot of each pair was used to study young seedlings. Four plots were designated as unsown controls used to monitor natural recruitment. Into the other 20 subplots, we added seeds to obtain synthetic communities with known initial compositions. Into these 'sown' plots, we sowed exactly 24 seeds, which were drawn randomly and evenly from a pool of $1,2,4,8$ or 12 species in order to generate variance in community composition. In these plots, we monitored only seedlings recruited from the seeds we added. In March 2005, seeds were 

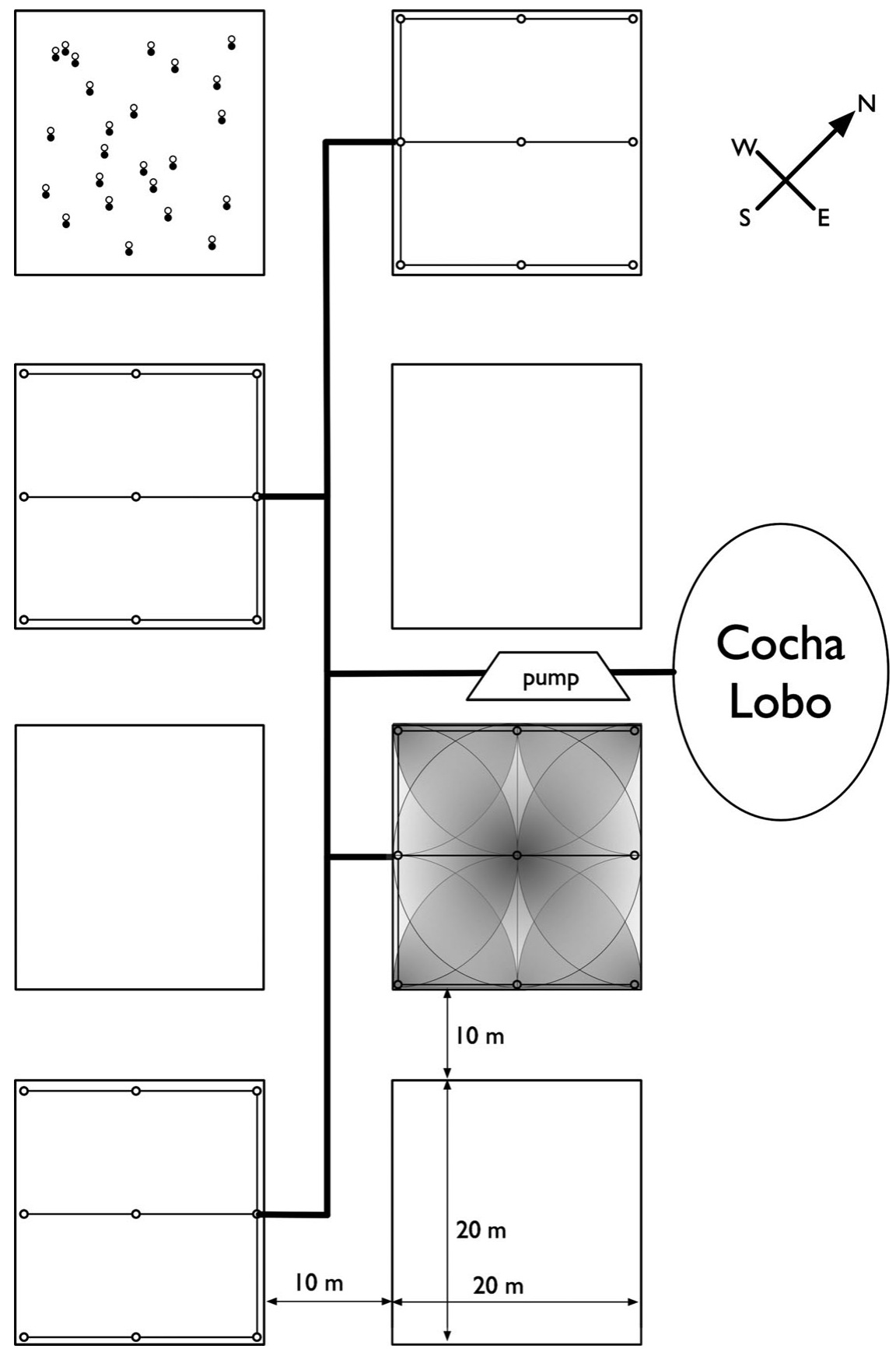

Figure 2. Schematic diagram of the experimental design. Watered plots were interspersed among unwatered plots. Each watered plot received at least $20 \mathrm{~mm}$ of supplemental precipitation twice-weekly from a grid of nine sprinkler heads. In all plots, seedlings were sampled in 24 sets of paired, randomly located $1-\mathrm{m}^{2}$ subplots. In one of each pair, older non-sown seedlings were monitored, whereas in the other, young seedlings recruited from sown seeds were monitored. They are denoted in the diagram by filled and unfilled circles, respectively.

manually sprinkled over plots without disturbing the soil in any manner (Paine \& Harms in press). The vegetation in each plot was lightly shaken to ensure that seeds settled to the surface of the leaf litter. Seed-addition plots were not protected against incursion by seed predators or herbivores.

Censuses for growth and survival occurred in March 2005, June 2005, January 2006 and January 2007.
Saplings were censused twice - in March 2005 and January 2007. The first census for older non-sown seedlings occurred in March 2005, whereas the first census of seedlings recruited from sown seeds occurred in June 2005, 3 mo after sowing. At all censuses, all seedlings were individually tagged, identified and their stem heights were measured to the nearest $\mathrm{cm}$. For sown seedlings, recruitment was defined to be synonymous 
with germination, whereas non-sown seedlings were defined as recruits only upon attaining a height of $10 \mathrm{~cm}$.

\section{Statistical analyses}

The individual-level responses of interest in this study were recruitment, growth and survival, and two of the community-level responses were density and diversity. Generalized linear models predicted each response variable as a function of date and watering treatment. Growth models were blocked on individuals nested within subplots nested within plots, and other models were blocked on plots only. The growth of small and large saplings was assessed separately. As measures of diversity, we assessed species richness and the Shannon and Simpson indices. Height, Shannon and Simpson indices were modelled as drawn from Gaussian distributions. For all three size-classes, survival was modelled as a binomial draw given the number of stems present in the previous census. Additionally, the recruitment and species richness of the synthetic communities recruited from sown seeds were modelled as binomial draws given the density and richness of the sown seeds. Other variables were count data, and were accordingly modelled as draws from Poisson distributions. An examination of residual plots indicated that these variables did not require transformation to meet model assumptions.

To assess community-level species compositional changes, an additional set of generalized linear models estimated the interaction between watering treatment and the habitat with which adults of each species were associated. These analyses averaged over observation dates and were performed only for young seedlings, since they recruited from experimentally sown seeds of known species composition.

All analyses were performed in R 2.8.0 (R Foundation, Vienna, Austria), using the nlme package for generalized linear models (Pinheiro \& Bates 2002).

\section{RESULTS}

Each watering event provided at least $20 \mathrm{~mm}$ of supplemental precipitation (or about $160 \mathrm{~mm} \mathrm{mo}^{-1}$ ). Supplemental watering thereby increased soil moisture throughout the dry season by $17 \% \pm 18 \%$ (mean \pm SD; Figure 1).

\section{Young seedlings recruited from sown seeds}

The effects of supplemental watering on the performance of individuals are presented in Figure 3. Of the 3840 seeds we sowed, $14.4 \%$ germinated and were observed as seedlings; 418 recruited within 4 mo of sowing, with an additional 103 and 32 seedlings germinating after 12 and 24 mo. Forty-one seedlings of sown species recruited as 'volunteers' in control subplots where no seeds were sown. The overall percentage of sown seeds that recruited did not differ between plots that received supplemental watering and those that did not (Figure 3a, deviance $=1.01$, $\mathrm{df}=1, \mathrm{P}=0.32$ ). There was a watering treatment $\times$ date interaction, driven by increased recruitment in June 2005 in watered plots (deviance $=8.4, \mathrm{df}=2$, $\mathrm{P}=0.01$ ). Seedlings in watered plots grew significantly more than those in unwatered plots (Figure 3d, watering $\times$ date interaction: $\mathrm{F}_{2,206}=4.2, \mathrm{P}=0.017$ ). Seedling survival was also significantly greater in plots that received supplemental watering (Figure $3 \mathrm{~g}$, deviance $=31.3, \mathrm{df}=1, \mathrm{P}<0.0001)$. Survival increased and became more similar between watered and unwatered treatments as seedlings grew and aged (date: deviance $=46.2, \mathrm{df}=1, \mathrm{P}<0.0001$; watering by date interaction: deviance $=8.9, \mathrm{P}=0.0003)$. Growth rates were correlated with survival probability: seedlings that grew substantially in the first census interval were more likely to survive to the end of the $2-y$ experiment (Logistic regression, deviance $=9.6, \mathrm{df}=1$, $\mathrm{P}=0.002$ ). Substantial mortality of seedlings recruited from sown seeds significantly reduced stem density and thus diversity over time in both treatments (Figure 3j, density: deviance $=21.7, \mathrm{df}=2, \mathrm{P}<0.0001$; richness: deviance $=60.7, \mathrm{df}=2, \mathrm{P}<0.001)$. Even so, watered plots had greater density and species richness than did unwatered plots (Density: deviance $=38.4$, $\mathrm{df}=1, \mathrm{P}<0.0001$; Richness: deviance $=10.6, \mathrm{df}=1$, $\mathrm{P}=0.0001)$. Results for all three diversity indices were similar. We therefore present only results for species richness.

\section{Older non-sown seedlings}

We monitored the fates of 1856 non-sown seedlings. Watering had no effect on their recruitment (Figure $3 b$, deviance $\leq 0.9, \mathrm{df}=1, \mathrm{P} \geq 0.34$ ). Before watering, seedlings in watered and unwatered plots were of similar height; thus there was no overall effect of watering on height of non-sown seedlings (Figure 3e, $\left.\mathrm{F}_{1,6}=1.76, \mathrm{P}=0.23\right)$. However, seedlings grown in watered plots grew taller than did seedlings in unwatered plots (watering by date interaction: $\mathrm{F}_{2,1943}=8.46$, $\mathrm{P}=0.0002$ ). The survival of non-sown seedlings was unaffected by the watering treatment (Figure $3 \mathrm{~h}$, deviance $=0.5, \mathrm{df}=1, \mathrm{P}=0.47)$. As with sown seedlings, seedling survival was positively associated with growth rate (Logistic regression, deviance $=8.0$, $\mathrm{df}=1, \mathrm{P}=0.005)$. Watered plots were significantly denser and more species-rich than unwatered plots (Figure 3k and 3n, Density: deviance $=14.3, \mathrm{df}=2$, $\mathrm{P}=0.001$; Richness: deviance $=4.6, \mathrm{df}=2, \mathrm{P}=0.03$ ). 
Sown seedlings

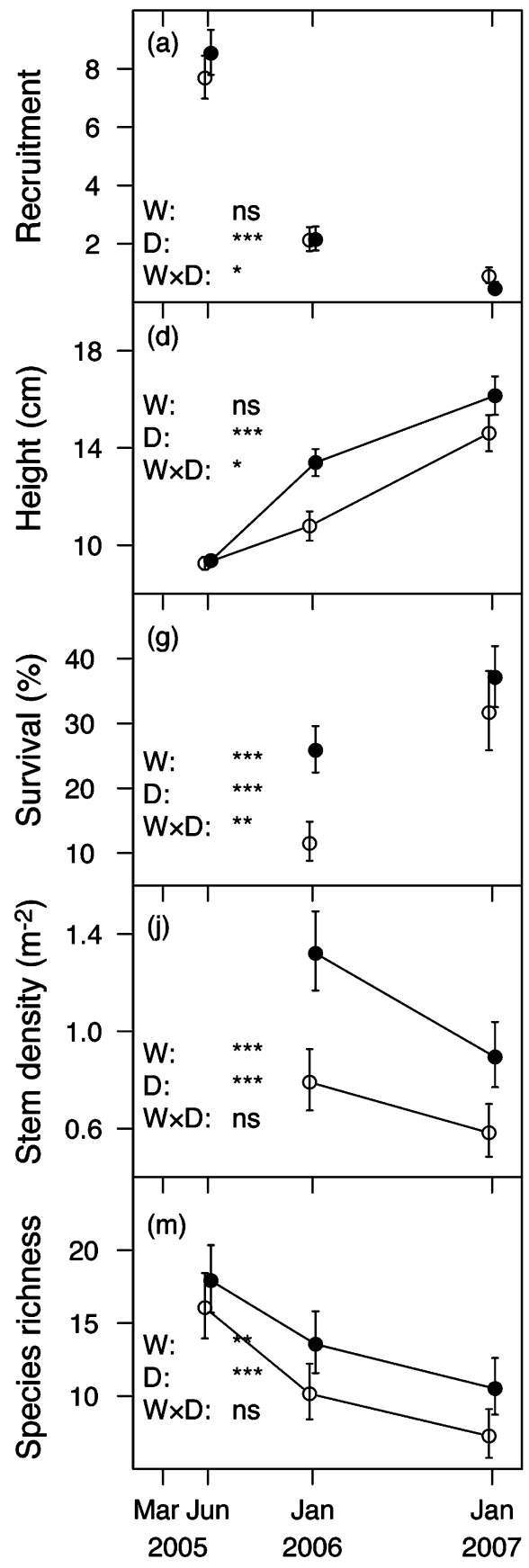

Non-sown seedlings

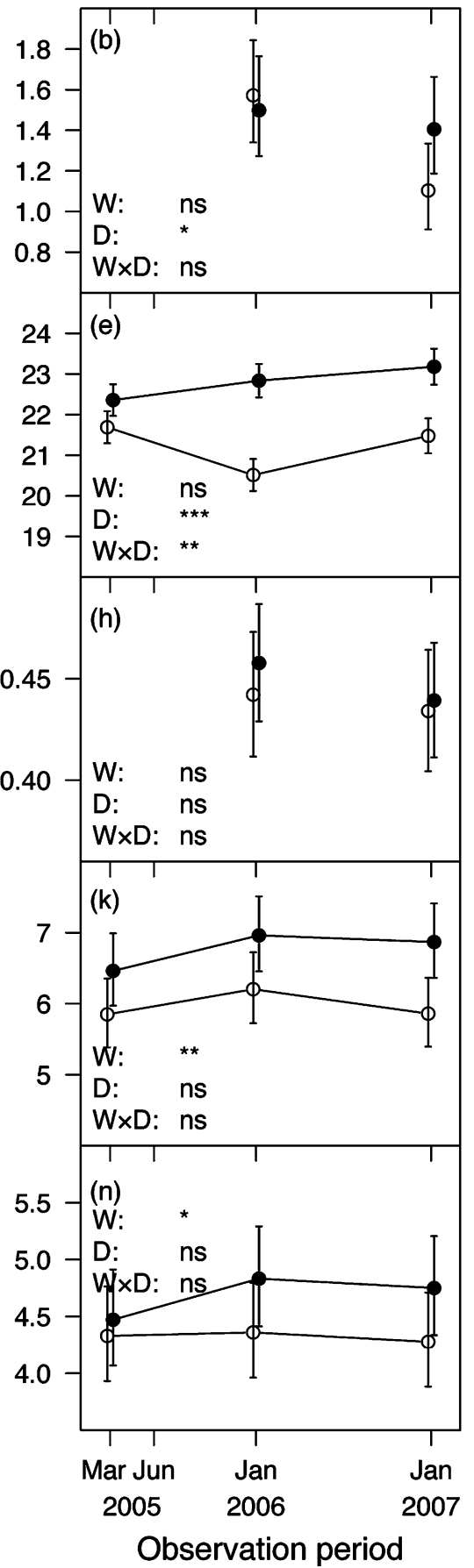

Saplings

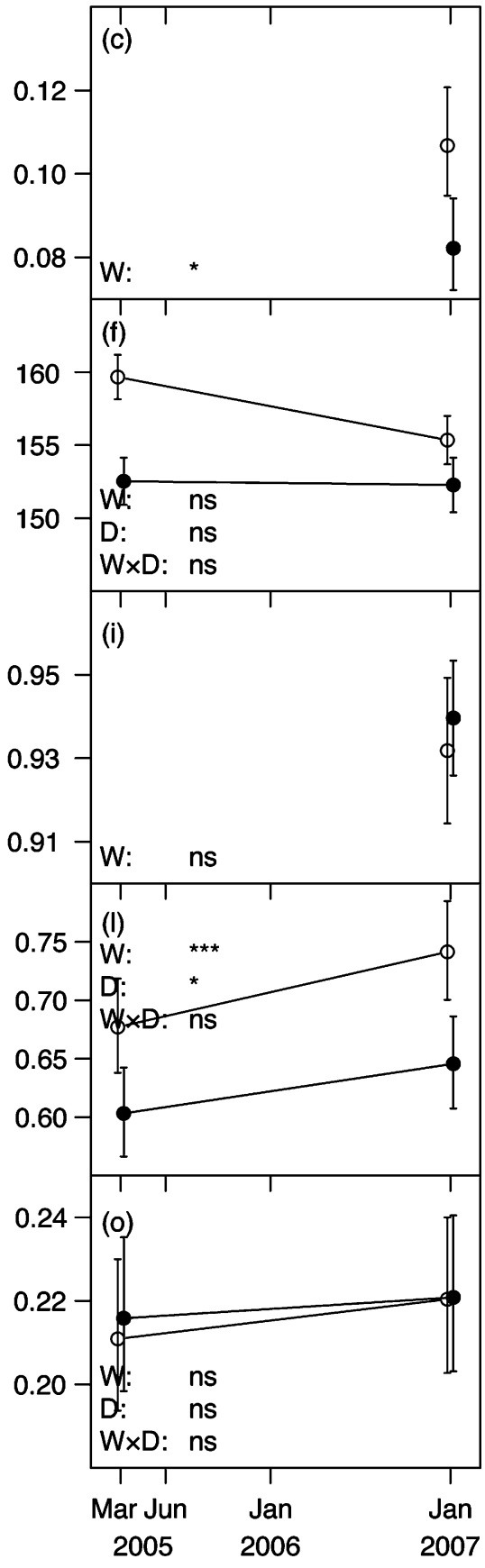

Figure 3. The effects of supplemental watering on individual performance varied among subsets of juvenile trees. Panels show recruitment (a, b, c), height (d, e, f), survival ( $\mathrm{g}, \mathrm{h}, \mathrm{i})$, stem density (j, k, l), and species richness (m, n, o) for young seedlings recruited from sown seeds (a, d, g, j, m), older non-sown seedlings (b, e, h, k, n) and saplings (c, f, i, l, o). Filled circles indicate watered plots and open circles indicate unwatered plots. Error bars indicate one SE. For sown seedlings, recruitment and species richness are expressed as percentages of the number of sown seeds or species (respectively), whereas for other size-classes they are expressed as counts of individuals or species. Codes in each panel indicate significance of the watering treatment $(\mathrm{W})$, date $(\mathrm{D})$, and their interaction $(\mathrm{W} \times \mathrm{D})$. Significance values are as follows: ${ }^{*}: \mathrm{P} \leq 0.05 ;{ }^{* *}: \mathrm{P} \leq 0.001 ;{ }^{* *}: \mathrm{P} \leq 0.0001$. Note that the y-axis scales vary among panels. Supplemental watering increased the survival and growth of young seedlings, but only the growth of older, naturally recruited seedlings. Supplemental watering did not affect the performance of saplings. 
However, because these differences were observed upon the initiation of the study, they cannot be attributed to the watering treatment.

\section{Saplings}

Supplemental watering had minimal effects on the performance of the 2353 saplings we monitored. More saplings recruited into the 1-m-tall size class in unwatered plots than watered plots (Figure 3c, deviance $=7.9, \mathrm{df}=1, \mathrm{P}=0.005$ ). Sapling recruitment led to significant increases in sapling stem density over time in both watered and unwatered plots (Figure 3i, deviance $=6.8, \mathrm{P}=0.009$ ). The density of watered plots was significantly less than that of unwatered plots (Density: deviance $=17.2, \mathrm{df}=1, \mathrm{P}<0.0001$ ). As for non-sown seedlings, however, this difference existed at the first census and cannot be attributed to the watering treatment. Otherwise, watering treatments had no substantial effects on the height growth of small saplings $\left(\mathrm{F}_{1,6}=1.4, \mathrm{P}=0.28\right)$, diameter growth of larger saplings, $\left(\mathrm{F}_{1,6}=0.05, \mathrm{P}=0.83\right.$; results not shown $)$, survival (deviance $=0.01, \mathrm{df}=1, \mathrm{P}=0.91$ ) or species richness $($ deviance $=0.08, \mathrm{df}=1, \mathrm{P}=0.77$ ).

\section{Interactions with habitat association}

We assessed the interactive effects of supplemental watering and habitat association on the performance of seedlings recruited from sown seeds with a separate set of generalized linear models. In general, supplemental watering boosted the performance of species associated with floodplain habitats, and diminished the performance of species associated with terra firme habitats. Recruitment of floodplain species was approximately twice that of terra firme species (Figure $4 \mathrm{a}$, deviance $=78$, $\mathrm{df}=1, \mathrm{P}<0.0001)$. Though watering had no overall effect on recruitment $($ deviance $=0.60, \mathrm{df}=1, \mathrm{P}=0.44$ ), it significantly decreased the recruitment of species associated with terra firme forests (deviance $=7.8$, $\mathrm{df}=1, \mathrm{P}=0.01)$. After recruitment, watering increased the survival of both terra firme and floodplain species similarly (Figure $4 \mathrm{~b}$, deviance $=12.0, \mathrm{df}=1$, $\mathrm{P}=0.001$ ), with no effect of habitat association (deviance $=0.01, \mathrm{df}=1, \mathrm{P}=0.99)$ and no significant interaction (deviance $=0.16, \mathrm{df}=1, \mathrm{P}=0.69$ ). These differential effects of recruitment and survival combined, such that the watering treatment increased the density and species richness of floodplain species while decreasing the density and species richness of terra firme species (Figure $4 \mathrm{c}$ and $4 \mathrm{~d}$, stem density: deviance $=20.0, \mathrm{df}=1$, $\mathrm{P}<0.0001$; species richness: deviance $=5.77, \mathrm{df}=1$, $\mathrm{P}=0.02)$.

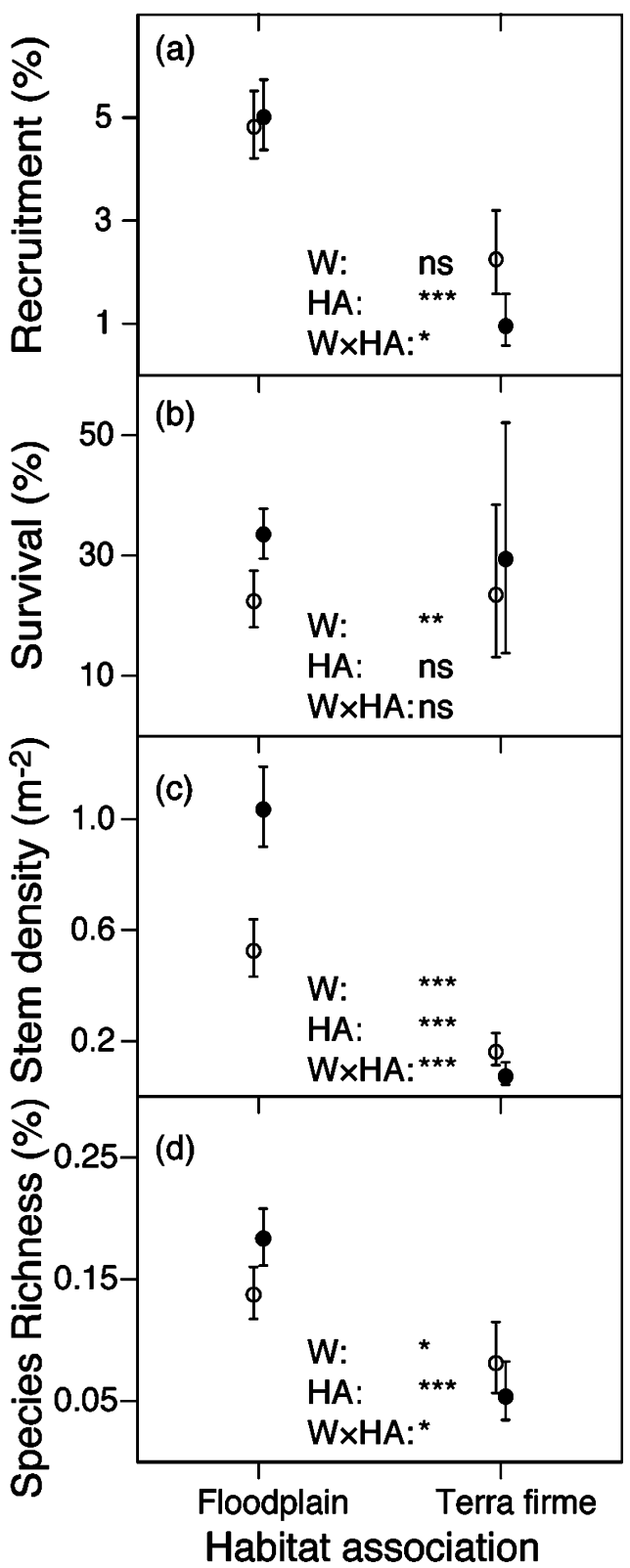

Figure 4. Seedlings of species associated with terra firme forests and floodplain forests responded differentially to the supplemental watering treatment. Panels show recruitment (a), survival (b), stem density (c), and species richness (d) of seedlings of species associated with terra firme and floodplain forests. Recruitment and species richness are expressed as a percentages of the number of seeds or species, respectively, sown into each plot. Codes in each panel indicate significance of the watering treatment $(\mathrm{W})$, habitat association $(\mathrm{HA})$ and their interaction $(\mathrm{W} \times \mathrm{HA})$. Symbols and significance values are as in Figure 3. Supplemental watering increased the performance of species associated with floodplain forests, while diminishing the performance of species associated with terra firme forests.

\section{DISCUSSION}

Our results indicate that seedling survival and growth, more than recruitment, vary with dry-season 
precipitation to affect seedling community structure. We thus found support for all three pathways linking water availability and local diversity, though to differing degrees. The survival and growth pathways were strongly supported. Regardless of habitat association, watering increased the survival of young seedlings. Watering also boosted growth, and individuals that grew more had an increased probability of surviving to the end of the experiment. On the other hand, there was little support for the third pathway, as supplemental precipitation had no overall effects on seedling recruitment, though it did reduce the initial recruitment of terra firme species. Our results thus diverge from those of previous studies, which found supplemental precipitation to affect seedling growth, but not survival (recruitment was not assessed; Bunker \& Carson 2005, Fisher et al. 1991, Yavitt \& Wright 2008).

Integrating the effects of recruitment, growth, and survival, increased dry-season precipitation boosted the density of young seedlings, though not older seedlings. Because we generated synthetic communities by sowing seeds, we were also able to test the effect of watering on diversity: watering also increased species richness for young seedlings. We attribute most of the positive relationship between supplemental watering and increased species richness to increased seedling survival.

Because variation in dry-season precipitation among years may be substantial, seedling responses to it may play an important role in shaping species distributions and limiting local diversity. For example, at Estación Biológica Los Amigos, where this study was conducted, the coefficient of variation in monthly dry-season precipitation between 2000 and 2007 was $48 \%$, compared with $35 \%$ for monthly rainyseason precipitation. Variation in dry-season seedling survival among forests may be an important mechanism underlying the relationship between water availability and diversity.

We must exercise caution in inferring linkages between seedling performance and habitat association as many functional traits may affect seedling recruitment and survival. Prominent among these is seed mass. For logistical reasons, our study did not include any very small-seeded species, which tend to be more light-demanding than are larger-seeded species ( $\mathrm{Paz} \&$ Martinez-Ramos 2003). Though the terra firme and floodplain species examined in this study both included ample range in seed mass, only three species were associated with terra firme forests. Further study linking seedling performance and water availability with more species, and in relation to functional traits may be very productive (Poorter \& Markesteijn 2008).

Our estimates of habitat association are based solely on the distribution of these species in south-eastern Amazonian Peru, though some species examined range throughout the Neotropics. Notably, Spondias mombin was found to be remarkably drought resistant in a Bolivian study (Poorter \& Markesteijn 2008). Nevertheless, the reduced recruitment of terra firme-associated species in watered plots suggests a mechanism that may restrict some of these species to drier habitats (Figure 4). For example, their seeds and seedlings may be more susceptible to water-borne pathogens, the prevalence of which is hypothesized to be greater in wetter habitats (Wright 1992). Our ability to test this hypothesis is limited since we did not explicitly examine pathogens in our study. Nevertheless, anecdotal evidence is consistent with this hypothesis. Iriartea deltoidea, the most common canopy palm throughout western Amazonia, was found at lower densities in watered plots than in unwatered plots at the end of the experiment, and its seedlings are susceptible to a pathogenic water-borne fungus, Diplodia mutila (Alvarez-Loayza et al. 2008). The prevalence of this and other pathogens may have been greater in watered plots. Further research into the epidemiology of fungal pathogens would be necessary to rigorously assess this hypothesis.

Conversely, the stem density of floodplain-associated species was significantly greater in watered plots than unwatered plots, whereas the survival of terra firme species did not differ. This pattern suggests that floodplain species may be less tolerant of seasonal drought than are terra firme species. Our data thus support recent results from studies in Panama and French Guiana (Baraloto et al. 2007, Engelbrecht et al. 2007), and is consistent with the hypothesis that differential seedling performance contributes to habitat associations.

There was a clear decrease in the influence of watering with ontogeny. Watering had strong effects on young seedlings recruited from sown seeds, relatively limited effects on older naturally recruited seedlings (increasing only growth rates), and no effects on the performance of saplings. Our results thus parallel those of Bunker \& Carson (2005). We infer these differences to be related to differential access to soil water and stored carbohydrates. In the floodplain forest where this experiment was conducted, the water table is not far beneath the surface, even in the dry season. Even so, larger plants have access to deeper sources of water, and should be better able to withstand periods of drought. With their greater height and leaf area, larger plants can produce greater stores of non-structural carbohydrate, easing them through periods in which respiration outlays are greater than photosynthetic income. This is suggested by the increase in survival for young seedlings through January 2006 and January 2007, as well as in the differences in survival among young seedlings, older seedlings and saplings (Figure 3).

In this experiment, we supplemented dry-season precipitation, and thereby decreased seasonality in precipitation. We did not modify any of the other factors associated with the rainy season that plants may utilize 
as phenological cues, such as cloudiness, leaf area index or day length. These factors, among others, may offset the increased individual performance imparted by supplemental watering. For example, individual performance in the rainy season may be limited by the reduction in light availability imposed by cloud cover, offsetting the effects of increased precipitation (Graham et al. 2003). A complete test of the effects of seasonality would require reciprocal transplantations between sites of differing degrees of seasonality.

We performed a field experiment to investigate the mechanisms that underlie the often-observed positive relationship between precipitation and tree-species diversity. Investigations of seedling performance are more frequently set in greenhouses, where light levels and consumer pressures (among other factors) may be controlled to a degree rarely found in forest settings. Alternatively, correlations have been drawn between plant performance and the occurrence of seasonal or ENSO-related droughts. This approach is complicated by the difficulty of disentangling the effects of water availability from other co-varying factors associated with natural droughts. In this field experiment, supplemental watering increased seedling growth and survival, though the effects of supplemental watering decreased with ontogeny. Furthermore, watering reduced the initial recruitment of terra firme-associated species while increasing the survival of floodplain species, generating shifts in community composition. Together, our results suggest that differential recruitment and survival at very early stages may contribute to the observed relationships between water availability, habitat associations, and patterns of tree species richness.

\section{ACKNOWLEDGEMENTS}

Nataly Hidalgo, Patricia Alvarez-Loayza, Christina Georgiou and Cecilia Carrasco helped to set up the watering system and measured multitudes of seedlings and saplings. We thank Nigel Pitman for his unreserved support and productive discussions, and the entire Los Amigos staff for logistical assistance. John Terborgh and Cesar Vela kindly provided unpublished data on adult tree densities. Comments from Liza Comita, Sarahfaye Mahon and three anonymous reviewers greatly strengthened the manuscript. This research was supported by a LSU Board of Regents fellowship to CETP and a NSF grant to KEH.

\section{LITERATURE CITED}

ALLEN, A. P., BROWN, J. H. \& GILLOOLY, J. F. 2002. Global biodiversity, biochemical kinetics, and the energetic-equivalence rule. Science 297:1545-1548.
ALVAREZ-LOAYZA, P., WHITE, J.F., BERGEN, M. \& CADENAS, C. 2008. Diplodia mutila causing seedling mortality of the palm Iriartea deltoidea. Plant Pathology 57:382.

BARALOTO, C., MORNEAU, F., BONAL, D., BLANC, L. \& FERRY, B. 2007. Seasonal water stress tolerance and habitat associations within four Neotropical tree genera. Ecology 88:478-489.

BUNKER, D. E. \& CARSON, W.P. 2005. Drought stress and tropical forest woody seedlings: effect on community structure and composition. Journal of Ecology 93:794-806.

CLINEBELL, R. R., PHILLIPS, O. L., GENTRY, A. H., STARK, N. \& ZUURING, H. 1995. Prediction of neotropical tree and liana species richness from soil and climatic data. Biodiversity and Conservation 4:56-90.

CONDIT, R., Aguilar, S., HERnÁNDEZ, A., PÉREZ, R., LAO, S., ANGEHR, G., HUBBELL, S. P. \& FOSTER, R. B. 2004. Tropical forest dynamics across a rainfall gradient and the impact of an El Niño dry season. Journal of Tropical Ecology 20:51-72.

DELISSIO, L. J. \& PRIMACK, R. B. 2003. The impact of drought on the population dynamics of canopy-tree seedlings in an aseasonal Malaysian rain forest. Journal of Tropical Ecology 19:489-500.

ENGELBRECHT, B. M. J. \& KURSAR, T. A. 2003. Comparative droughtresistance of seedlings of 28 species of co-occurring tropical woody plants. Oecologia 136:383-393.

ENGELBRECHT, B. M. J., COMITA, L., CONDIT, R., KURSAR, T. A., TYREE, M. T., TURNER, B. L. \& HUBBELL, S. P. 2007. Drought sensitivity shapes species distribution patterns in tropical forests. Nature 447:80-82.

FISHER, B. L., HOWE, H. F. \& WRIGHT, S. J. 1991. Survival and growth of Virola surinamensis yearlings: water augmentation in gap and understory. Oecologia 86:292-297.

FOSTER, S. A. \& JANSON, C. H. 1985. The relationship between seed size and establishment conditions in tropical woody plants. Ecology 66:773-780.

GRAHAM, E. A., MULKEY, S. S., KITAJIMA, K., PHILLIPS, N. G. \& WRIGHT, S. J. 2003. Cloud cover limits net $\mathrm{CO}_{2}$ uptake and growth of a rainforest tree during tropical rainy seasons. Proceedings of the National Academy of Sciences of the USA 100:572-576.

HARMS, K. E., CONDIT, R., HUBBELL, S. P. \& FOSTER, R. B. 2001. Habitat associations of trees and shrubs in a 50-ha neotropical forest plot. Journal of Ecology 89:947-959.

HARPER, J. L. 1977. Population biology of plants. Academic Press, London. $892 \mathrm{pp}$.

HOLDRIDGE, L. R. 1947. Determination of world plant formations from simple climatic data. Science 105:367-368.

KREFT, H. \& JETZ, W. 2007. Global patterns and determinants of vascular plant diversity. Proceedings of the National Academy of Sciences of the USA 104:5925-5930.

LEWIS, S. L. \& TANNER, E. V. J. 2000. Effects of above- and belowground competition on growth and survival of rain forest tree seedlings. Ecology 81:2525-2538.

NEPSTAD, D. C., TOHVER, I. M., RAY, D., MOUTINHO, P. \& CARDINOT, G. 2007. Mortality of large trees and lianas following experimental drought in an Amazon forest. Ecology 88:2259-2269.

PAINE, C. E. T. \& HARMS, K. E. in press. Quantifying the effects of seed arrival and environmental conditions on tropical seedling community structure. Oecologia. DOI: 10.1007/s00442-008-1269-6. 
PAZ, H. \& MARTINEZ-RAMOS, M. 2003. Seed mass and seedling performance within eight species of Psychotria (Rubiaceae). Ecology 84:439-450.

PEÑA-CLAROS, M. \& DE BOO, H. 2002. The effect of forest successional stage on seed removal of tropical rain forest tree species. Journal of Tropical Ecology 18:261-274.

PHILLIPS, O. L., HALL, P., GENTRY, A. H., SAWYER, S. A. \& VASQUEZ, R. 1994. Dynamics and species richness of tropical rain-forests. Proceedings of the National Academy of Sciences of the USA 91:28052809.

PINHEIRO, J. C. \& BATES, D. M. 2002. Mixed-effects models in $S$ and S-PLUS. Springer, Berlin. 528 pp.

PITMAN, N.C. A., TERBORGH, J. W., SILMAN, M. R., NUNEZ, P., NEILL, D. A., CERON, C. E., PALACIOS, W. A. \& AUleSTIA, M. 2002. A comparison of tree species diversity in two upper Amazonian forests. Ecology 83:3210-3224.

POORTER, L. \& MARKESTEIJN, L. 2008. Seedling traits determine drought tolerance of tropical tree species. Biotropica 40:321-331.
TANNER, E. V. J. \& BARBERIS, I. M. 2007. Trenching increased growth, and irrigation increased survival of tree seedlings in the understorey of a semi-evergreen rain forest in Panama. Journal of Tropical Ecology 23:257-268.

WILLIAMSON, G. B., LAURANCE, W. F., OLIVEIRA, A. A., DELAMONICA, P., GASCON, C., LOVEJOY, T. E. \& POHL, L. 2000. Amazonian tree mortality during the 1997 El Niño drought. Conservation Biology 14:1538-1542.

WRIGHT, S. J. 1992. Seasonal drought, soil fertility and the species density of tropical forest plant-communities. Trends in Ecology and Evolution 7:260-263.

WRIGHT, S. J. \& CORNEJO, F. H. 1990. Seasonal drought and leaf fall in a tropical forest. Ecology 71:11651175.

YAVITT, J. B. \& WRIGHT, S. J. 2008. Seedling growth responses to water and nutrient augmentation in the understorey of a lowland moist forest, Panama. Journal of Tropical Ecology 24:1926. 